\title{
Novas tendências da Revista de Psiquiatria do Rio Grande do Sul
}

\author{
Revista de Psiquiatria do Rio Grande do Sul: new trends
}

\author{
Flávio Kapczinski ${ }^{1}$, Jair Segal ${ }^{2}$, Pedro Vieira da Silva Magalhães ${ }^{2}$, Rodrigo Grassi de Oliveira ${ }^{2}$ \\ ${ }^{1}$ Editor-chefe e ${ }^{2}$ editores associados, Revista de Psiquiatria do Rio Grande do Sul.
}

Os editores da Revista de Psiquiatria do Rio Grande do Sul e a diretoria da APRS iniciaram um trabalho de qualificação da revista com o objetivo principal de garantir que a mesma pudesse permanecer indexada nas bases de dados que já haviam sido conquistadas e, além disso, concorrer a novas e melhores indexações, principalmente em bases internacionais. Nesse sentido, uma série de transformações foram planejadas e vêm sendo executadas.

A primeira grande mudança foi a implementação de um novo sistema de submissão online, o ScholarOne Manuscripts, visando aumentar a qualidade do fluxo editorial. Essa mudança possibilitou que a Revista de Psiquiatria do Rio Grande do Sul adotasse o mesmo sistema utilizado pelos principais periódicos do mundo. O sistema permite que o autor acompanhe passo a passo o processo editorial e que indique potenciais revisores para avaliar seu manuscrito (a indicação de revisores não desejados também é possível). A configuração de alto nível do ScholarOne Manuscripts oferece visões gerais sobre a situação de cada artigo e identifica gargalos, visando maximizar a capacidade de trabalho da equipe e agilizar o fluxo editorial. Com esse sistema, os editores podem gerenciar de maneira mais eficaz a atribuição e execução de diferentes tarefas, enviar lembretes via e-mail e utilizar ferramentas automáticas de pesquisa baseadas na web. Além de todas as vantagens operacionais, o uso do ScholarOne Manuscripts pretende fomentar a participação de autores internacionais, uma vez que a plataforma possui uma interface muito fácil de usar e bastante popular internacionalmente.

Outras metas dos editores atuais no processo de qualificação da revista foram manter um processo de qualidade científica crescente dos artigos aceitos e preservar a característica de um rápido processo editorial.

Todavia, uma das maiores mudanças está por vir. Iniciando no próximo número, referente a dezembro de 2011, a Revista de Psiquiatria do Rio Grande do Sul passará a se chamar Trends in Psychiatry and Psychotherapy. O primeiro volume sob o novo nome trará transformações substanciais no projeto editorial e gráfico da revista. A linha editorial essencial da revista se mantém, porém com foco nos avanços das áreas de psiquiatria e psicoterapia, incluindo também suas interfaces, como psicologia e neurociências.

A preferência pelo idioma inglês nas submissões novas, a partir de 2011, também foi implementada com o objetivo de atingir uma audiência internacional. Todavia, a submissão de artigos em língua portuguesa ainda pode ser realizada.

Nos últimos anos, a crescente procura pela revista tem exigido uma série de transformações visando o constante aperfeiçoamento técnico e científico do periódico. Tais transformações vêm se consolidando no sentido de pautar um planejamento estratégico para levá-la a atingir a classificação A1 do sistema Qualis/Capes, bem como ser incluída em outros importantes indexadores, principalmente MEDLINE e ISI.

Todas essas mudanças descritas são fruto de inúmeras reuniões entre os editores e a diretoria da APRS. Alguns dos frutos já podem ser observados: além dos indexadores ABEC, BIOSIS, PsycINFO e SciELO, nossa revista foi recentemente indexada no SCOPUS e na EMBASE. Certos de que estamos no caminho certo, esperamos que, em breve, outros frutos também possam ser colhidos. 